UC-10

Issued: September 1984

Ln- -10169-11S

DE85 005187

\title{
Nonaqueous Processing Methods
}

\author{
M. S. Coops* \\ D. F. Bowersox
}

\begin{abstract}
DISCLAIMER
This repon was prepared as an account o! work sponsored by an agency of the United States Government. Neither the United States Government nor any agency thereof, nor any of their employees, makes any warranty, express or implied, or assumes any legal liability or responsibility for the accuracy, completeness, or usefulness of any information, apparatus, product, or process disclosed, or represents that its use would not infringe privately owned rights. Reference herein to any specific commercial product, process, or service by trade name, trademark, manufacturer, or otherwise does not necessarily constitute or imply its endorsement, recommendation, or favoring by the United States Government or any agency thereof. The views and opinions of authors expressed herein do not neressarily state or reffect those of the United States Gover?ment or any agency thereof.
\end{abstract}




\title{
NONAQUEOUS PROCESSING METHODS
}

\author{
by
}

M. S. Coops and D. F. Bowersox

\section{ABSTRACT}

\begin{abstract}
A high-temperature process utilizing molten salt extraction from molten metal alloys has been developed for purification of spent power reactor fuels. Experiments with laboratory-scale processing operations show that purification and throughput parameters comparable to the Barnwell Purex process can be achieved by pyrochemical processing in equipment one-tenth the size, with all wastes being discharged as stable metal alloys at greatly reduced volume ano disposal cost. This basic technology can be developed for large-scale processing of spent reactor fuels.
\end{abstract}

\section{I . INTRODUCTION}

Pyrochemical processing methods offer the potential of large cost reductions ovr.r traditional aqueous chemical processes proposed for fissile material recovery. The recovery techniques that we propose require no cooling period for iodine decay prior to processing and do not generate volatile species during the processing steps. These processes conserve expensive shielded cell space by using highly compact process hardware. In many steps the process reagents can be recycled because pyrochemical reagents, unlike aqueous reagents, are highly radiation resistant. The minimal amount of wastes arising from these processes is generated as solid materials and rarely requires additional processing prior to packaging for ultimate disposal.

This report is a result of our discussions at the EPRI Workshop on FissionFusion Hydride Fuel Cycle Risks in La Jolla, California, April 25-30, 1982. One smail working group dealt with the reprocessing of the spent fuel and blanket 
material. Since the primary hybrid was suppressed tission of either a metal Be-Th or a metal Be-U blanket to $0.2-0.6 \%$ burnup, the molten metal/molten salt processing is particularly promising. The process is based on the salt transport process and metal processing performed in the 1960 s and can be extended to include spent power reactor fuels. However, small-scale demonstration and considerable engineering will be required before the process could be adopted.

The nonaqueous methods discussed here are proven chemical processes which have been demonsirated in laboratory-scale operations. In spite of this, we anticipate that a significant engineering effort will be required to design and manufacture the operating hardware needed for reliable, trouble-free remote operations in the hostile environments encountered within shielded process modules. Pyrochenical processes are, in many ways, similar to the more traditional solvent extraction systems in that separations are accomplished by extracting a chemical family, such as the actinides, out of a solvent with an extractant. The great difference is that in pyrochemical systems the solvent is typically a molten alloy, the extractant is a mixture of molten salts, and the operating temperature is about $800^{\circ} \mathrm{C}$. Common solvent alloys contain magnesium, copper, zinc, or bismuth; common extraction salts are various combinations of alkali or alkaline earth halides, commonly chloride salts ( $\mathrm{NaCl}, \mathrm{KCl}, \mathrm{MgCl}_{2}, \mathrm{CaCl}_{2}$ ). Fluoride salt melts, which are especially corrosive, can occasionally be used to great advantage in processes where the product elements can be volatilized from the process as hexafluoride gas $\left(\mathrm{UF}_{6}, \mathrm{PaF}_{6}, \mathrm{PuF}_{6}\right)$.

Process extractions may be carried out in batches, in counter-flow columns, 1 or in mixer-settler extractors. ${ }^{2}$ Because of the corrosive nature of molten salts, process equipment must be constructed from metals that are highly resistant to chemical attack. Process equipment designed for use with fluoride-bearing salts is commonly made from molybcenum or Hastelloy-N $N^{R}$, and equipment intanded for use with chloride salts can be made from tantalum, tungsten, and, in certain cases, titanium and zirconium. Because the oxides of these refractory metals are volatile at elevated temperatures, pyrochemical process equipment must be contained in inert atmospheres such as argon or helium. The technology of operating inertatmosphere cells with master-slave manipulators has been successfully demonstrated. 3

Process temperatures in pyrochemical separations range from $400^{\circ} \mathrm{C}$ to $900^{\circ} \mathrm{C}$, depending on the salts selected for optimum separation characteristics. The soluvility of elements such as uranium, plutonium, and the fission products is at least as large in molten salts and alloys as in common aqueous solvents (nitric or 
hydrochloric acids) and, in many cuses, is ar order of magnitude larger. The net heavy-metal density in typical pyrocherical processes is a factor of 10 greater than in comparable aqueous systems. Therefore, pyrochemical processes equipment can be small in physical size and yet match the throughput capability of much larger aqueous process hardware.

The reaction kinetics of pyrochemical systems is extremely fast. In experimental evaluation of a counter-current extractor at ANL, the rate-limiting step was the time needed for dissolved metal to diffuse from the center of a solvent droplet to the surface. The equilibrium extraction time for the unit was related to the size of the droplet generated by the distributor plate for the solvent metal. Therefore, the mass throughput of such a column is limited only by physical "flooding" of the extractor plates. Since the specific gravity ratio of molten salts to liciuid metals is large, the mass throughput per unit area is much greater than for organic extractant systems.

\section{SALT TRANSPORT PROCESS}

We believe the ANL Salt Transport Process (STP) would be a superior method for performing fissile material recovery and providing a suitable decontamination from fission products. The process utilizes the difference in distribution coefficients between iwo metal phases and a common transport salt. Alloys containing a common alloying element are used to prevent contamination of the phases with foreign solvents. For example, binary alloys of magnesium can be used with magnesium chloride as the bridge between two halves of a simple Redox process. The foilowing information from Process Chemistry, Series III, Volume 4 presents an insight into the chemistry of the Salt Transport method of chemical purification. ${ }^{4}$

Many factors enter into the selection of liquid metal solvent systems, such as melting point, vapor pressure, and solubility relatonships. of particular interest in a process involving separations by salt-metal extraction methods are the effects of metal phase composition upon the distribution behavior of uranium, plutonium, and the fission-product elements. The distribution coefficients of individual elements and the separation factors between elements can both be changed markedly by varying the composition of the metal phase.

\footnotetext{
*Information provided by R. D. Pierce, Argonne National Laboratory, Novenber 4, 1980.
} 
In Fig. 1, the distribution behavior of praseodymium between a 50 mol\% $\mathrm{MgCl}_{2}-30 \mathrm{~mol} \% \mathrm{NaCl}-20 \mathrm{~mol} \% \mathrm{KCl}$ salt phase and various binary alloys of magnesium is shown. Much of the experimental work on salt-metal extraction method; has been done with tracer-level radioactive praseodymium besause it behaves as a typical rare-earth fission product and is a convenient element for radiochemical analysis. As muy be seen in Fig. 1, the praseodymium distribution coefficient is about $10^{5}$ times larger for a $\mathrm{Cu}-67 \mathrm{wt} \% \mathrm{Mg}$ alloy than it is for an $\mathrm{Al}-20 \mathrm{wt} \% \mathrm{Mg}$ a $\mathrm{i}-$ loy. This pronounced effect is due to the large differences in the activities of praseodymium and magnesium in these two alloys.

The composition of the metal phase has a strong effect, not only on the disLribution coefficients, but also on the separation factors that can be: obtained for various solutes. Because of the importance of the plutonium/rare-earth separation ia pyrochemical processes, several experiments ha\% examined the effect of separations. The praseodymium/plutonium separation factor depended upon the magnesium content of the liquid alloy, the other constitutent of the alloy, and the temperature. The effects of these three factors are illustrated in Fig. 2, where the praseodymium/plutonium separation factor is plctted against the magnesium content of the alloy shase for binary allcy of magnesium with copper, zinc, and cadmium at $600^{\circ} \mathrm{C}$. In all cases, the salt phase compc ion was the ternary system, $50 \mathrm{~mol} \% \mathrm{MgCl}_{2}, 30 \mathrm{~mol} \% \mathrm{NaCl}$, and $20 \mathrm{nol} \% \mathrm{KCl}$. The effect of temperature may he secll by comparing the curves for the copper-magnesium system at $600^{\circ} \mathrm{C}$ and $800^{\circ} \mathrm{C}$. The effect of magnesium cencentration is in qualitative agreement with the prediction from the activity copficients of praseodymium and plutonium in the four pure solvents. At $600^{\circ} \mathrm{C}$, these values indicate that the separation factors in the pure metals should differ by the following factors: 1.6 for magnesium and cadmium, 3.4 for magnesium and zine, and 490 for magnesium and copper. These predicted values agree with the values estimated from Fig. 2 .

Largely because of the data shown in Fig. 2, a 33 wt. $\mathrm{Cu}-67 \mathrm{wt} \% \mathrm{Mg}$ is often selected as the liquid metal solvent for the reduction and rare-earth extraction steps of the STP flowsheec. This alloy has the highest observed rare-earth/ piutonium separation factor, and ts relatively low melting point $\left(\sim 590^{\circ} \mathrm{C}\right)$ permits operation at a reasonable temperawure.

Salt transport sepcrations ace based upon selective transfer of a solute from one liquid metal alloy (donor) to another (acceptor) by contacting the two alloys either alternately or simultaneously with the same molten salt. This method can be used to separate plutonium from uranium and the nobrar-metal fission products. 





The donor and acceptor alloys contain the same metal that is the weaker reducing agent (Mg), and the salt contains the complementary oxidizing agent (Mgri $\left.1_{2}\right)$. The alloys also contain one or more soivent me Lais that are weaker reducing agents than magnesium, e.g., zinc, cadmium, copper. The magnesium concentrations in the alloys and the solvent metal are selected so that the thermodynamic properties of the system will favor the desired separation. The salt transport step for plutonium recovery and purification employs a 33 wt\% Cu-67 wt\% Mg donor alloy, a $\mathrm{Zn}-5$ wt\% $\mathrm{Mg}$ acceptor alloy, and a $50 \mathrm{~mol} \% \mathrm{Cl}_{2}-30 \mathrm{~mol} \% \mathrm{NaCl}-20 \mathrm{~mol} \% \mathrm{KCl}$ salt phase.

The salt transport of plutonium is illustrated schematically in Fis. 3 . The plutonium in the donor alloy is oxidized by $\mathrm{MgCl}_{2}$ and extracted into the salt:

$$
\mathrm{Pu}(\mathrm{Cu}-\mathrm{Mg})+\frac{3}{2} \mathrm{MgCl}_{2}(\mathrm{salt}) \rightarrow \mathrm{PuCl}_{j}(\mathrm{salt})+\frac{3}{2} \mathrm{Mg}(\mathrm{Cu})
$$

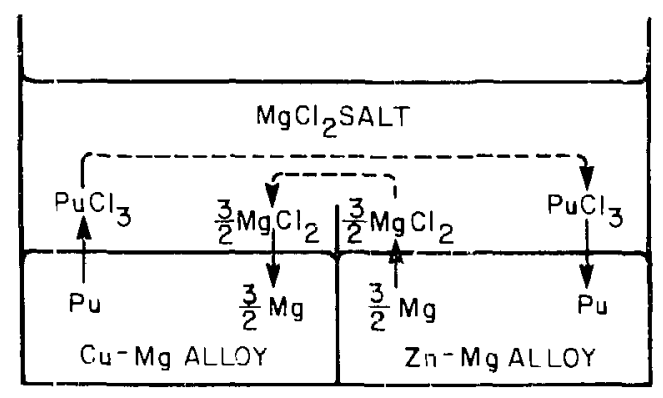

Fig. 3. Schematic illustration of calt transport step for plutonium.

The salt containing the $\mathrm{PuCl}_{3}$ is then contracted with the zinc-magnesium acceptor alloy, where the reverse reaction takes place:

$$
\mathrm{PLCl}_{3}(\mathrm{sal} t)+\frac{3}{2} \mathrm{Mg}(\mathrm{Zn}) \rightarrow \mathrm{Pu}(\mathrm{Zn}-\mathrm{Mg})+\frac{3}{2} \mathrm{MgCl}_{2} \text { (salt) }
$$

The overall reaction is

$$
\mathrm{Pu}(\mathrm{Cu}-\mathrm{Mg})+\frac{3}{2} \mathrm{Mg}(\mathrm{Zn}) \rightarrow \mathrm{Pu}(\mathrm{Zn}-\mathrm{Mg})+\frac{3}{2} \mathrm{Mg}(\mathrm{Cu})
$$

For each mole cf plutonium transferred from the donor to the acceptor, 1.5 moles of magnesium move in the opposite direction. The depletion of magnesium in the 
acceptor alloy and its increasing concentration in the donor alloy must be taken into account in the practical application of a salt transport separation.

\section{A. Typical Process}

A typical STP is diagrammed in Fig. 4. The process equipment consists of three counter-current vertical extraction columns arranged in parallel. A salt pump is used to circulate the molten transport salt through all three cclumns. The process material, probably consisting of uranium with plutonium and fission products, is placed in the donor alloy (33 wt\% $\mathrm{Cu}-67 \mathrm{wt} \% \mathrm{Mg}$ ) and into the first column. The uranium is dissolved at the rate that is transported across the salt bridge to the acceptor reservoir. The transition and noble-metal fission products will remain in the donor loop. A small side stream from the donor column effluent is shunted to a distillation unit to remove the fission-product residues from this stream. Eventually the transition and noble-metal products will be discharged to waste as a copper alloy with no additional waste solidification treatment.

The actinide and rare-earth elements will be extracted into the transport salt, $50 \mathrm{~mol} \% \mathrm{MgCl}_{2}-30 \mathrm{mc} 1 \% \mathrm{NaCl}-20 \mathrm{mul} \% \mathrm{KCl}$, but only the actinides will he reextracted -nto the acceptor alloy (95 wt\% $\mathrm{Zn}-5 \mathrm{wt} \% \mathrm{Mg}$ ). The small mass of rareearth fission products can build up in the transport loop for a considerable time or can be removed in the third column by a stripping alloy (50 wt\% $\mathrm{Al}-50 \mathrm{wt} \% \mathrm{Mg}$ ). The rare earths can be disposed of as alloys in a metallic aluminum matrix with no further waste treatment.

The uranium will exceed the solubility of the acceptor alloy and be removed from the process as metallic fines; ${ }^{5}$ plutonium will remain in the acceptor solvent and be recovered by distillation of the solvent me-al.

The entire process can be housed in a single argnn-atmosphere hot cell of rather small dimensions. For example, all process equipment required could easily be housed in the EBR-II argon-atmosphere hot cell known as HFEF-North.

B. Alternate Processes

Another viable, demonstrated method for the recovery of $\mathrm{Pa}, \mathrm{U}, \mathrm{Np}$, and $\mathrm{Pu}$ from irradiated fue]s is the volatilization of the respective hexafluoride gas from a fluidized bed containing alumina and the fuel in the form of oxide, chloride, or tetrafluoride salt. ${ }^{6}$ Either fluorine or another strong fluorinating agent is passed through the bed with an inert carrier gas at temperatures ranging from $300^{\circ} \mathrm{C}$ to $600^{\circ} \mathrm{C}$, and the volatile hexafluoride gases are trapped from the flowing gas stream on $\mathrm{NaF}$ or $\mathrm{MgF}_{2}$ traps operated at temperatures ranging from 
$\infty$

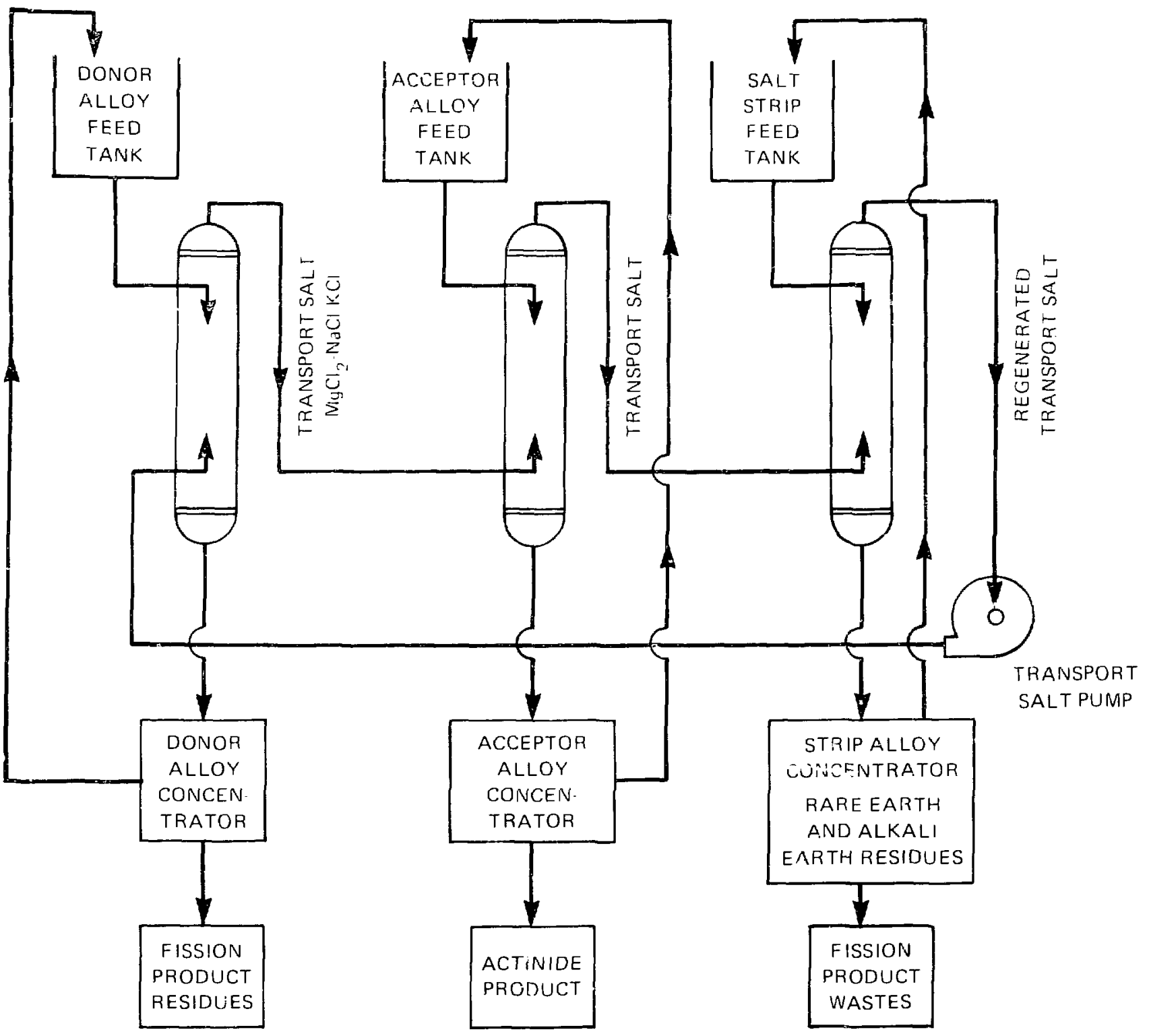

NOTES:

DONOR ALLOY:

$33 \mathrm{w} \% \mathrm{Cu}, 67 \mathrm{wr} \mathrm{Mg}$ ACCEPTOR ALLOY:

95 w1\% Zn, 5 wt \% Mg

SALT REGENERATING ALLOY:

$50 w t \% \mathrm{Al}, 50 \mathrm{wt} \% \mathrm{Mg}$

PROCESS CELL ATMOSPHERE:

ARGON GAS, 1 atn

TEMPERATURE:

- 800 C FOR EXTRACTORS

MATERIAL:

TANTALUM COLUMNS, PIPING FEED RATE:

- $1 / 2$ GPM METAL ALLOY

- 3 GPM EXTRACTION SALT

Fig. 4. Salt transport process schematic diagram, iranium recovery 
$100^{\circ} \mathrm{C}$ to $400^{\circ} \mathrm{C}$. The few volatile fission products can be readily fractionated from the actinide elements on these traps, and after decontamination, the actinides can be recovered by elution off the traps and conversion to the tilterable tetrafluoride. ${ }^{7}$ This is done either by thermal decomposition of the hexafluoride or photoreduction with high-intensity light of the proper frequency. Unused fluorinating agents can be recycled back through the process for reuse.

It is also possible to separate actinide elements from each other by the volatility technique. For example, plutonium can be isolated from uranium by first passing $\mathrm{BrF}_{5}$ through the bed containing $\mathrm{UO}_{2}-\mathrm{PuO}_{2}$ at $300^{\circ} \mathrm{C}$. Only $\mathrm{UF}_{6}$ is volatilized from the bed and is collected on NaF traps; then $F_{2}$ is passed through the bed at $550^{\circ} \mathrm{C}$ and the $\mathrm{PuF}_{6}$ is collected on a different set of traps.

It is probable that $\mathrm{PaF}_{5}$ and $\mathrm{UF}_{6}$ can be isolated from thorium by a similar volatilization technique; the nonvolatile $\mathrm{ThF}_{4}$ can be reduced to metal with cadmium at $800^{\circ} \mathrm{C}$ and recycled back to the blanket for reuse.

The utilization of molten fluoride salts as both a reactor coolant and breeding blanket has been thoroughly demonstrated at ORNL during the development of a molten salt power reactor. ${ }^{8}$ Many detailed discussions of both the chemistry and engineering techniques associated with this method exist in the current literature.9,10 Since the technology of flowing molten fluoride salts is fully developed and doclmented, we will not comment further on this method other than to cite polentially serious problems involving neutronic compatibility between the alloys required for corrosion resistance to the salts and those required for optimum breeding characteristics in the blanket. If these problems can be satisfactorily resolved, this technique would be an excellent method for recovering boih ${ }^{233} \mathrm{~Pa}$ and ${ }^{233} \mathrm{U}$ from circulating molten salts in a hybrid reactor. Warren Grimes has written an excellent discussion of this subject as part of the report on the feasibility of the fission-suppressed tandem mirror hybrid reactor concept.11

After bulk removal of the major constituent of the blanket, a partial separation of fission products can be achieved by melt-refining or electrorefining processes.

In melt refining, the uranium or praseodymium from the blanket would be maintained for several hours bith an oxide slag such as magnesia.12 The melt would then be separated, probably by pouring, from the slag and the purified uranium (or plutonium) separated.

Electrorefining of plutonium has been very successful at Los Alamos and, from 1964 through 1977, about $1570 \mathrm{~kg}$ of pure piutonium has been produced from 
metal fabrication scrap. ${ }^{13}$ This electrolytic conversion replaced many processing steps requiced in plutonium recovery by aqueous methods. Electrorefining is a smallscale operation at Los Alamos; however; it is an excellent method for purification of active metals when molten salt electrolytes are employed.

\section{REFFRENCES}

1. T. R. Johnsor, R. D. Pierce, F. T. Teats, and E. F'. Johnson, "Behavior of Countercurrent Liquid-liquid Columns with a Liquid Metal," (Argonne National Laboratory), American Institute of Chemical Engineers, Sixty-First Annual Meeting, Los Angeles, California, Paper 24F, December 1, 1968.

2. J. B. Knighton, G. J. Berstein, G. N. Vargo, and R. D. Pierce, "Development of a Mixer-Settler for Liquid Metal Salt Systems," Argonne National Laboratory report ANL-7810 (June 1971).

3. J. P. Bacsa, "Hot Fuels Examination Facility - North (Experimental Breeder Reactor-Il Site) Basic Facility System Design Description: Document No. W001-0400-SA-01," Argonne National Laboratory - West, Idaho National Engineering Laboratory - West, Idaho National Engineering Laboratory, Idaho Falls, Idaho (December, 1976).

4. R. K. Stuenberg, R. D. Pierce, and L. Burris, "Progress in Nuclear Chemistry," Piocess Chemistry, Series III, Vol. 4, pp. 46l-504 (Pergamon Press, 0xford, $1970)$.

5. J. K. Bates, L. J. Jardine, and M. Krumpelt, "Actinide Separation," ACS Symposium Series 117, J. D. Navratil and W. W. Schulz, Ed., American Chemical Society, Washington, D. C. (1980), pp. 207-217.

6. A. A. Jonke, "Development of Volatility Processes for Thermal and Fast Reactor Fuels," Proceedings of the Rocky Flats Volatil.jty Conference, June 24, 1968, J. M. Cleveland, Ed., AEC report CONF-680610 (June, 1968).

7. Norman M. Levitz et al., "A Conceptual Design Study of a Fluoride-Volatility Plant for Reprocessing LMFBR Fuels," Argonne National Laboratory report ANL-7583 (July 1969).

8. M. W. Rosenthal, P. N. Hankerreich, and R. B. Briggs, "The Development Status of Molten Salt Breeder Reactors," Oak Ridge National Laboratory report ORNL-4812 (August 1972).

9. L. E. McNeese, Ed., "Program Plan for Development of Molten Salt Breeder Reactor:" Oak Ridge National Laboratory report ORNL-4812 (August 1972).

10. Murray in Rosenthal et al., "The Status and Technology cf Molten-SaIt Reactors - A Review of Molten Salt Reactor Work at the Oak Ridge National Laboratory," Nuclear Applications and Technology, February 1970, Vo1. 8, No. 2, Published by American Nuclear Society, pp. 105-208. 
11. J. D. Lee et al., "Feasibility Study of a Fission-Suppressed Tandem-Mirror Hybrid Reactor," Lawrence Livermore Nati nal Laboratory report UCID-19327 (April 1982).

12. D. C. Hampson, R. M. Fryer, and J. i. Rizzie, "Meit Refining of EbR-II Fuels," Nuc1. Metal1. 15, 57 (1969).

13. I. J. Mullins and A. N. Morgan, "A Review of Operating Experience at the Los Alamos Plutonium Electrorefining Facility, 1963-1977," Los Alamos National Iaboratory report LA-8943 (December 1981). 